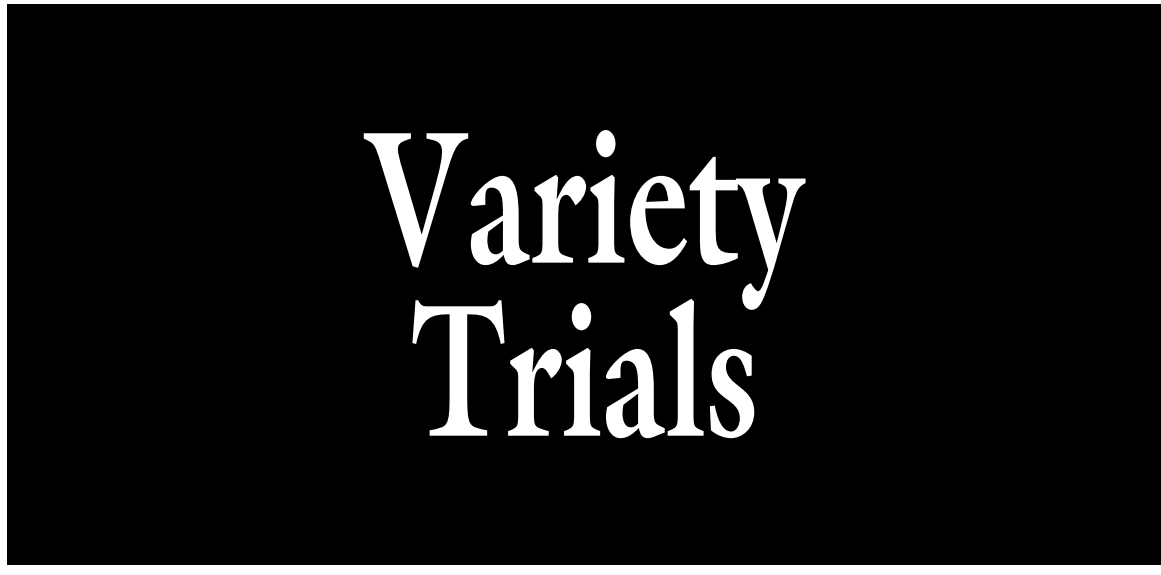

\section{Performance and Tolerance to Phytophthora Blight of Bell Pepper Varieties}

\author{
Amara R. Dunn ${ }^{1}$, Lindsay E. Wyatt ${ }^{2}$, Michael Mazourek ${ }^{2}$, \\ Stephen Reiners ${ }^{3}$, and Christine D. Smart ${ }^{1,4}$
}

Additional Index words. Phytophthora capsici, oomycete, disease resistance, Capsicum annuum, fruit quality, silvering, skin separation

SUMMARY. In 2011, total marketable yield, fruit size, and number of lobes; fruit discoloration due to silvering; and plant structure were compared among eight commercial green bell pepper (Capsicum annuиm) varieties and four breeding lines at three field sites in central New York. Tolerance to phytophthora blight (Phytophthora capsici) was also assessed at one of these sites. No wilting or plant death due to phytophthora blight was observed on the four breeding lines. 'Paladin', 'Intruder', and 'Aristotle' had the highest levels of tolerance to phytophthora blight, among the commercial varieties and maintained their yields in the presence of disease. In the absence of phytophthora blight, yields from these three varieties were comparable to susceptible varieties, but fruit tended to be smaller, and incidence of silvering was high in 'Paladin' and 'Intruder'. Less silvering was observed on 'Aristotle' fruit. Total marketable yields from the breeding lines and percent of fruit with four lobes was comparable to the commercial varieties, and some breeding lines also had a low incidence of silvering, but fruit were smaller and set later in the season. Overall, this study suggests that 'Paladin', 'Intruder', and 'Aristotle' will yield well in fields with a history of severe phytophthora blight, but new large-fruited varieties with low incidence of silvering and good tolerance to phytophthora blight are needed.

I $\mathrm{n}$ the United States, 56,200 acres of bell pepper were planted in 2011 , with a total production value of just under $\$ 685$ million [U.S. Department of Agriculture (USDA), 2012b]. However, desirable traits vary from region to region, based on a variety of factors, including the growing conditions in the region (e.g., climate and predominant soil type), major diseases affecting the region, the market for which peppers are grown (e.g., fresh vs. processing), and whether fruit will be harvested green or when reaching their mature color (e.g., red or yellow) (Crosby, 2008). This results in different varieties being preferred by growers in different parts of the country. For example, 'Revolution' yielded well in a Pennsylvania trial (Sánchez et al., 2011), but performed poorly in Maine where the growing season is shorter and generally cooler (Hutton and Handley, 2007).

In New York State, the majority of fruit are harvested green. Production was valued at $\$ 9.9$ million in 2010 (the last year for which data are available) on 1200 acres (including upstate and Long Island), and all are grown for the fresh market (USDA, 2012a). For fresh market, not only total yield but also fruit size, shape, and appearance affect the value of the crop and are important characteristics when New York growers select a bell pepper variety. For the highest grades, USDA standards require that fruit be at least 2.5 inches (for U.S. No. 1 grade) or 3 inches (for U.S. Fancy grade) in diameter, free from damage or injury, and not misshapen (USDA, 2005). In addition, early-yielding plants with fruit that are blocky, larger (4 inches diameter), thick walled, and have four lobes are increasingly desirable for fresh market production in the United States. (Crosby, 2008).

One abiotic disorder that can reduce the value of bell pepper fruit or make it completely unmarketable is skin separation, often called "silvering." These mottled patches of white or silver on the fruit surface are superficial but can reduce marketability, especially if they cover large areas of the fruit (Kline et al., 2011). One study reported up to $66 \%$ of fruit affected by silvering on a single harvest date (Wyenandt and Kline, 2006). Previous work has shown that incidence of silvering can vary by harvest date, field site, and the rate and type of fertilizer applied, but pepper variety appears to be the most important and consistent factor (Kline et al., 2011). Interestingly, fruit silvering tends to be more common on bell pepper varieties with tolerance to the disease phytophthora

\begin{tabular}{llll}
\hline $\begin{array}{l}\text { Units } \\
\text { To convert U.S. to SI, } \\
\text { multiply by }\end{array}$ & U.S. unit & SI unit & $\begin{array}{l}\text { To convert SI to U.S., } \\
\text { multiply by }\end{array}$ \\
\hline 0.4047 & $\mathrm{acre}(\mathrm{s})$ & $\mathrm{ha}$ & 2.4711 \\
29.5735 & $\mathrm{fl} \mathrm{oz}$ & $\mathrm{mL}$ & 0.0338 \\
0.3048 & $\mathrm{ft}$ & $\mathrm{m}$ & 3.2808 \\
3.7854 & gal & $\mathrm{L}$ & 0.2642 \\
2.54 & inch(es) & $\mathrm{cm}$ & 0.3937 \\
6.4516 & inch & $\mathrm{cm}^{2}$ & 0.1550 \\
0.4536 & $\mathrm{lb}$ & $\mathrm{kg}$ & 2.2046 \\
1.1209 & $\mathrm{lb} / \mathrm{acre}$ & $\mathrm{kg} \cdot \mathrm{ha}^{-1}$ & 0.8922 \\
0.0254 & mil & $\mathrm{mm}$ & 39.3701 \\
28.3495 & $\mathrm{oz}$ & $\mathrm{g}$ & 0.0353 \\
& & &
\end{tabular}


blight, whereas it is less common on more susceptible varieties (Kline et al., 2011).

Phytophthora blight is a soilborne disease caused by the oomycete Phytophthora capsici (Leonian, 1922). Once phytophthora blight is on a farm, it is essentially impossible to eradicate from the soil and can result in severe yield losses in pepper because of fruit rot and plant death (Granke et al., 2012). This disease may have been introduced to New York State as early as the mid-1930s, when infected watermelon (Citrullus lanatus var. lanatus) fruit shipped from Colorado were observed in New York City markets (Wiant and Tucker, 1940). It is now present on many New York vegetable farms (Dunn et al., 2010), in vegetable production regions across the United States and around the world (Granke et al., 2012). Because of the large host range [including eggplant (Solanum melongena), tomato (Solanum lycopersicum), snap bean (Phaseolus vulgaris), and cucurbits (Cucurbitaceae)] and the increasing prevalence of insensitivity to fungicides (Dunn et al., 2010; Jackson et al., 2012; Keinath, 2007), host resistance is a key component to successful management of phytophthora blight. Many commercial bell pepper varieties with varying levels of tolerance to phytophthora blight are available, including 'Paladin' (highly tolerant but not completely immune), 'Revolution', and 'Aristotle' (both showing intermediate levels of tolerance) (Foster and Hausbeck, 2010; McGrath and Fox, 2009). The genetic basis of this tolerance is not clearly understood, but involves multiple genes (Ortega et al., 1992), with tolerance to different disease symptoms (i.e., stem and root rot,

\footnotetext{
We thank Holly Lange and Maryann Fink-Brodnicki for technical assistance. Support for Amara R. Dunn was provided by a fellowship from Cornell University College of Agriculture and Life Sciences. The project was funded through a grant from the NY State Department of Agriculture and Markets Specialty Crop Block Grant. Support for Lindsay Wyatt was provided by a Cornell University Presidential Life Sciences Fellowship and USDA National Needs Graduate Fellowship Competitive Grant No. 2008-38420-04755 from the National Institute of Food and Agriculture.

${ }^{1}$ Department of Plant Pathology and Plant-Microbe Biology, Cornell University, 630 West North Street, Geneva, NY 14456

${ }^{2}$ Department of Plant Breeding and Genetics, Cornell University, 248 Emerson Hall, Ithaca, NY 14853

${ }^{3}$ Department of Horticulture, Cornell University, 630 West North Street, Geneva, NY 14456

${ }^{4}$ Corresponding author. E-mail: cds14@cornell.edu.
}

fruit rot, or leaf lesions) being conferred by different genes (Sy et al., 2005).

Like all plant diseases, the severity of phytophthora blight in any year depends on inoculum abundance, the presence of a susceptible crop, and the occurrence of favorable environmental conditions. These conditions include warm air temperatures (Mchau and Coffey, 1995) and periodic flooding or soil saturation events (because of heavy rainfall, overirrigation, or poor soil drainage) (Bowers and Mitchell, 1990). Therefore, predicting disease pressure before the season begins is difficult. If bell pepper varieties with tolerance to phytophthora blight have less desirable traits (e.g., fruit silvering or smaller fruit size), then growers will need to weigh this information against the history of disease severity (and probable inoculum level) in their fields. The objectives of this study are to 1 ) determine which commercial bell pepper varieties have the best combination of yield, fruit quality traits, and tolerance to phytophthora blight when grown under conditions similar to those on vegetable farms in upstate New York (i.e., relatively heavy soil and moderate temperatures), in the presence and absence of disease pressure, and 2 ) compare phytophthora-tolerant pepper breeding lines to commercially available varieties.

\section{Materials and Methods}

FIELD sites. These experiments were conducted at three field sites: two located at the New York State Agricultural Experiment Station in Geneva, NY, and one at the East Ithaca research farm of Cornell University in Ithaca, NY. The Ithaca field site (hereafter referred to as "Ithaca") and one field site in Geneva ("Geneva") are located on vegetable research farms with no history of phytophthora blight and the soil types are Arkport sandy loam and Lima loam, respectively. At the second Geneva site (hereafter referred to as "Geneva-P"), vegetables have been inoculated with $P$. capsici annually since 2007 , but no overwintering population of the pathogen is present. The soil is Odessa silt loam. The Geneva site was treated with trifluralin (4EC; Albaugh, Ankeny, IA) at the labeled rate to control weeds 3.5 weeks before transplanting. At all sites, raised beds were 4 inches high and $3 \mathrm{ft}$ wide, with $7 \mathrm{ft}$ between centers and covered with 1.25-mil black- embossed plastic mulch (Belle Terre Irrigation, Sodus, NY). At the time beds were built, $300 \mathrm{lb} /$ acre $10 \mathrm{~N}-$ 4.4P-8.3K fertilizer (Phelps Supply, Phelps, NY) was applied under the mulch, and drip tape (12 inches between holes and flow rate of $0.45 \mathrm{gal} /$ min per $100 \mathrm{ft}$; Toro, Bloomington, $\mathrm{MN}$ ) was laid under the mulch, slightly off center.

Pepper varieties and culture. Five commercially available bell pepper varieties described by the supplier as being "intermediate" in their tolerance to phytophthora blight and three varieties not described as tolerant (although one of these, 'Aristotle' is known to have tolerance to phytophthora blight, as discussed above) were selected for this experiment. All eight varieties are grown commercially in New York State for the fresh market and usually harvested green. In addition, four breeding lines were also included (Table 1). Pepper seedlings were grown in a greenhouse under supplemental and natural light, using heated mats to improve germination. On 8 (Geneva site) and 10 (Geneva-P and Ithaca sites) June 2011, 6.5-week-old seedlings were transplanted in single rows with 18 inch spacing between plants. At each site, plants were arranged in a randomized complete block design, with each block containing 10-plant plots of each variety (with the exception of Pcap-NY8007-1, for which only five or six plants were available per plot at the Geneva and Geneva-P sites, because of limiting seed and germination). At all sites, blocks were replicated four times across adjacent rows in the field. At transplant, a total of $1.6 \mathrm{lb}$ soluble fertilizer (Peters Excel 21N-2.2P-16.6K; JR Peters, Allentown, PA) was applied across the four blocks via a water wheel transplanter at an approximate rate of 0.07 gal per foot of row $(2 \mathrm{lb}$ fertilizer per $50 \mathrm{gal}$ water). Total monthly rainfall at Geneva and Geneva-P sites was 2.34, 0.72, and 2.62 inches for June, July, and August, respectively. At the Ithaca site, total monthly rainfall was 2.59 , 1.99 , and 4.63 inches for June, July, and August, respectively. Plants were irrigated using drip tape to supplement rainfall as needed.

INOCULATION WITH PHYTOPHTHORA BLIGHT. A New York isolate of P. capsici [NY 0664-1 (obtained from pepper in 2006)] was used to inoculate 
Table 1. Bell pepper varieties and breeding lines used in trials and the tolerance to phytophthora blight of commercially available varieties as advertised by the suppliers.

\begin{tabular}{|c|c|c|}
\hline Variety or breeding line & $\begin{array}{c}\text { Phytophthora blight } \\
\text { tolerance }^{\mathrm{z}}\end{array}$ & Source \\
\hline Declaration & Intermediate & $\begin{array}{l}\text { Harris Moran Seed Co., } \\
\text { Modesto, CA }\end{array}$ \\
\hline Intruder & Intermediate & Syngenta, Greensboro, NC \\
\hline Paladin & Intermediate & Syngenta \\
\hline Revolution & Intermediate & Harris Moran Seed Co. \\
\hline Vanguard & Intermediate & Harris Moran Seed Co. \\
\hline Aristotle & NA & $\begin{array}{l}\text { Seminis Vegetable Seeds, } \\
\text { St. Louis, MO }\end{array}$ \\
\hline Karisma & NA & Harris Moran Seed Co. \\
\hline Red Knight & NA & Seminis Vegetable Seeds \\
\hline Pcap-NY8001-1 & & Cornell breeding line \\
\hline Pcap-NY 8002-3 & & Cornell breeding line \\
\hline Pcap-NY 8006-1 & & Cornell breeding line \\
\hline Pcap-NY 8007-1 & & Cornell breeding line \\
\hline
\end{tabular}

${ }^{2} \mathrm{NA}=$ not advertised by supplier as tolerant to phytophthora blight, regardless of whether tolerance has been demonstrated in research trials.

the Geneva-P site. To induce sporulation, the isolate was cultured on plates of V8-juice agar at room temperature under fluorescent lights $15 \mathrm{~h}$ per day for 7 to $10 \mathrm{~d}$. Plates were then flooded with sterile distilled water, and sporangia (asexual spores) were dislodged using an L-shaped spreading rod. On 24 June (plants were 8.5 weeks old), sporangia from 17 plates were collected (total volume of $\approx 300 \mathrm{~mL}$ ) and this suspension was incubated at room temperature for $\approx 30 \mathrm{~min}$ to allow zoospore release. The concentration of zoospores was quantified using a hemocytometer, and $\approx 5 \mathrm{~mL}$ of suspension $\left(4 \times 10^{4}\right.$ zoospores $\left./ \mathrm{mL}\right)$ were applied at the crown of each plant using a 1.5-gal hand pump sprayer. On 6 and 19 July, the inoculation was repeated with $5 \mathrm{~mL}$ of suspension $\left(1 \times 10^{5}\right.$ zoospores $/ \mathrm{mL}$ ) following similar procedures, but inoculum was applied higher up the stem of the plants (where stem tissue was still green) and allowed to run down the stem to the soil surrounding the plant. Beginning 29 June, the proportion of plants in each plot showing symptoms of phytophthora blight (either wilting or death) was recorded about twice weekly, with the final disease rating on 21 Sept.

Harvest. Beginning 28 July, 2 Aug., and 11 Aug. at the Ithaca, Geneva, and Geneva-P sites, respectively, mature green fruit were harvested about every 2 weeks for a total of four harvests at each site. Harvests at the Geneva-P site included mature fruit from symptomatic plants, if fruit were present. At all sites, height, width, and height to first fruit for each plant were measured just before the first harvest. These data were not collected for dead plants at the Geneva-P site. In addition, uprightness of plants was rated on a per plot basis using a scale from 1 (completely prostrate) to 3 (upright) at the first harvest date (all sites), midway through harvest (Ithaca site), or the last harvest date (Geneva and Geneva-P sites). At the first harvest date, only, the ease with which fruit could be picked was also rated at all sites on a scale from l (many branches break off during harvest) to 3 (fruit can be harvested easily without breaking branches).

After harvest, unmarketable fruit were sorted into the following categories: affected by silvering (covering at least one square inch of the surface of the pepper), having symptoms of phytophthora blight (at Geneva-P site, only), and otherwise unmarketable (fruit misshapen or damaged by blossom end rot or insects). Marketable fruit were sorted by maximum diameter (less than 2 inches, $2-2.5$ inches, 2.5-3 inches, 3-3.5 inches, 3.5-4 inches, and greater than 4 inches), and fruit with diameters less than 2 (Geneva and Geneva-P sites) or 2.5 (Ithaca site) inches were designated unmarketable. At all harvest dates, the total weight of fruit in each of the above categories was recorded for each plot, and the total weight of marketable fruit (adjusted to weight per 10 plants) was calculated for each plot at each harvest date. Yields at the Geneva-P site were adjusted per 10 plants that were healthy at the first inoculation date (24 June), to account for yield loss because of plant death. At the first harvest, the total number of marketable fruit per plot was counted and used to obtain an average weight per marketable fruit and average number of fruit per plant. At all harvests, 10 marketable fruit per plot (if available) were arbitrarily selected from all marketable size categories and the following measurements were made on each fruit: number of lobes, length, width at stem end, and width at blossom end. The number of lobes per fruit was then used to calculate the percent of marketable fruit with four lobes (most desirable for fresh bell peppers for local markets).

Statistical analysis. Because all plants in the fourth block at the Geneva site were markedly stunted compared with plants in the other three blocks (probably due to a problem with irrigation), data from this block were excluded, and all analyses for this site were performed with data from three blocks, rather than four. The R statistical software (R Development Core Team, 2012) was used to conduct analysis of variance (ANOVA) on all data. In addition, the "car" package (Fox and Weisberg, 2011) was used to do a repeated measures ANOVA on total weight of marketable fruit (with harvest date and variety as independent variables) to determine if harvest date was a significant factor. If it was, then total marketable fruit weight was also analyzed on each harvest date, separately. Following all significant ANOVAs $(P<0.05)$, means were separated with a Tukey's honestly significant difference (HSD) test (at alpha $=0.05)$ using the "agricolae" package (de Mendiburu, 2012). For each site, the following data were summed across all four harvest dates before analysis: weight of total marketable fruit, weight of large fruit [at least 3 inches in diameter, which is the minimum diameter for fruit to be graded as U.S. Fancy (USDA, 2005)], and percent (by weight) of fruit affected by silvering. Average fruit weight and average number of fruit per plant were analyzed on only the first harvest date (Geneva and Geneva-P sites) or the second harvest date (Ithaca site), and data from the first and second harvest dates (Geneva and Geneva-P 


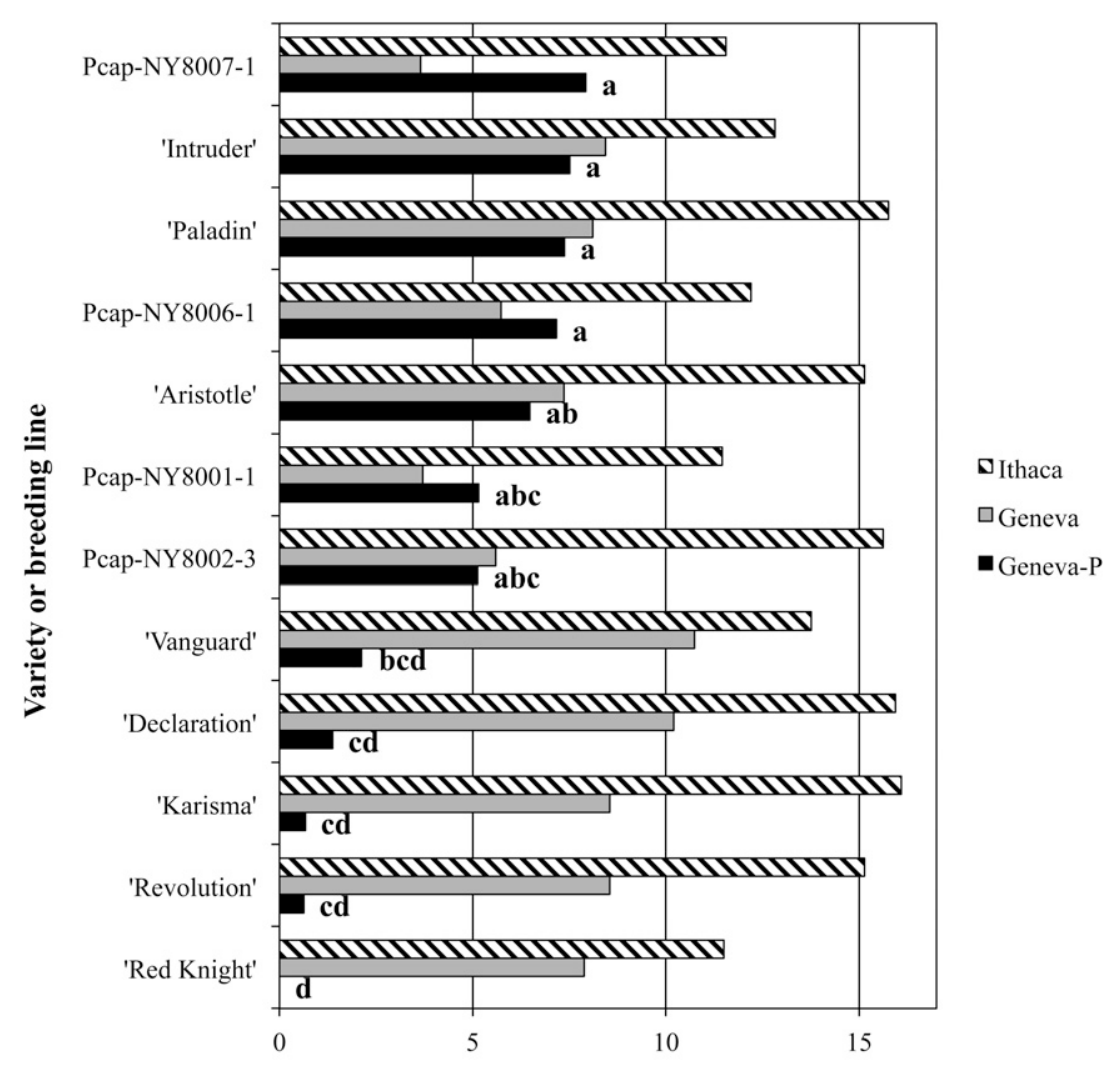

Mean marketable yield (kg/10 plants)

Fig. 1. Total marketable yield of green bell pepper varieties and breeding lines at three field sites in New York State. At one site (Geneva-P), plants were inoculated with Phytophthora capsici on 24 June, and at the other two sites (Geneva and Ithaca), plants were not inoculated. Yields are total weight $(1 \mathrm{~kg}=2.2046 \mathrm{lb})$ of fruit from all marketable size categories summed across four harvest dates at each site, and are adjusted per 10 plants (or per 10 plants healthy before inoculation with

phytophthora blight at the Geneva-P site) to account for plots that had fewer than 10 plants. Marketable fruit were defined as being greater than 2 or 2.5 inches $(5.08$ or $6.35 \mathrm{~cm}$ ) in diameter at Geneva and Geneva-P, or Ithaca sites, respectively, and without blemishes from diseases, insects, or abiotic disorders. At the Geneva-P site, bars followed by the same letter are not significantly different at $P<0.05$ (analysis of variance $P<0.001$ ). Differences between varieties at the Geneva and Ithaca sites were not significantly different at $P<0.05$.

sites), and second and third harvest dates (Ithaca site) were combined for analysis of fruit dimensions and lobe number. At the Geneva-P site, ANOVA followed by a Tukey's HSD test was conducted on disease incidence from the final rating date.

\section{Results}

Differences in weight of total marketable fruit (summed over all marketable size categories and harvest dates) among varieties and breeding lines were only significant at the Geneva-P site (Fig. 1), where yield closely paralleled disease tolerance (Fig. 2). Yields from 'Vanguard', 'Declaration', 'Karisma', and 'Revolution' at the Geneva-P site did not differ significantly from 'Red Knight' (which had no marketable yield). Therefore, these five varieties were considered highly susceptible to phytophthora blight and excluded from analyses of mean percent large fruit, percent of marketable yield affected by silvering, fruit size, and lobe number, at the Geneva-P site, only. These varieties will hereafter be referred to as "susceptible," in spite of advertised tolerance in 'Vanguard', 'Declaration', and 'Revolution' (Table 1). Under heavy disease pressure, yields from Pcap-NY8007-1, 'Intruder', 'Paladin', and Pcap-NY8006-1 were significantly larger than from all five susceptible varieties. In addition, 'Aristotle', Pcap-NY8001-1, and PcapNY8002-3 produced significantly larger yields than 'Red Knight'.
'Intruder', 'Paladin', and 'Aristotle' will subsequently be referred to as "tolerant" to phytophthora blight, in spite of the fact that 'Aristotle' is not marketed as such (Table 1). Possibly due to limited rain events during peak fruit production, we observed very few fruit with symptoms of phytophthora blight, so no comparisons of fruit rot incidence were made among varieties and breeding lines. The mean number of marketable fruit per plant per harvest ranged from two to three fruit at both the Geneva and Geneva-P sites, and from two to five fruit at the Ithaca site, but differences among varieties were not significant at any of the three sites (data not shown).

While differences in total weight of marketable fruit were not significant in the absence of pressure from phytophthora blight, there were significant differences in the proportion of fruit classified as "large" (at least 3 inches in diameter). At all sites, the four breeding lines tended to produce fewer large marketable fruit than did the commercial varieties, although these differences were not always significant (Table 2). Under pressure from phytophthora blight, 'Paladin' produced the highest proportion of large fruit, significantly more than two of the breeding lines but not significantly more than 'Aristotle' or 'Intruder'. In the absence of disease pressure, there were no significant differences in proportion of large fruit among commercial varieties at either the Geneva or Ithaca sites. However, at both sites, the commercial varieties with the highest proportion of large fruit had significantly more large fruit than at least two of the breeding lines. In general, more large fruit were produced at the Ithaca site than at either the Geneva or Geneva-P sites.

Similarly, marketable fruit from the breeding lines numerically tended to have smaller mean weights and to be shorter than marketable fruit from commercial varieties (Table 3 ). Differences in mean weight were not significant at either the Geneva or Geneva-P sites, but at the Ithaca site, Pcap-NY8007-1 and Pcap-NY8001-1 produced marketable fruit that weighed significantly less than fruit from ' $\mathrm{Rev}$ olution', 'Paladin', 'Declaration', 'Intruder', and 'Karisma'. All breeding lines had average fruit weights significantly less than that of 'Revolution' at this site. Under heavy disease 


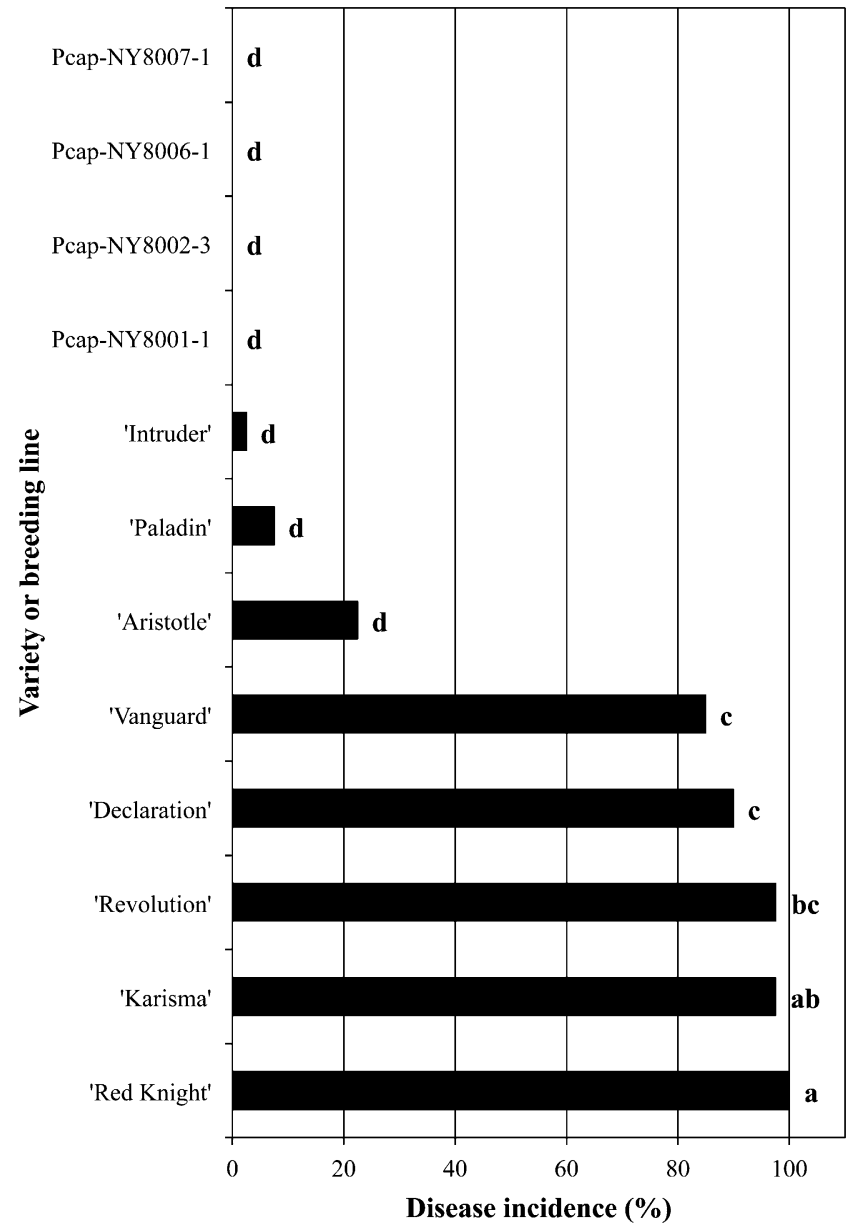

Fig. 2. Incidence of phytophthora blight on green bell pepper varieties and breeding lines grown at the Geneva, NY, site inoculated with Phytophthora capsici on 24 June (Geneva-P). Disease incidence is the proportion of plants per plot showing symptoms of phytophthora blight (wilting or plant death) on 21 Sept. Means followed by the same letter are not significantly different at $P<0.05$ (analysis of variance $P<0.001$ ).

pressure at the Geneva-P site, all breeding lines produced significantly shorter fruit than the three tolerant varieties (Paladin, Intruder, and Aristotle). At the Geneva and Ithaca sites, these differences were not always significant, but trends were similar. Percent of fruit with four lobes differed significantly among varieties only at the Geneva-P site, with PcapNY8002-3 having a significantly higher percent of marketable fruit with four lobes compared with the three tolerant commercial varieties (Paladin, Intruder, and Aristotle). There were no significant differences among commercial varieties in fruit weight, percent of fruit with four lobes, or fruit length. Differences in mean fruit width at the stem end were only significant at the Geneva-P and Ithaca sites, but differences were small in magnitude, ranging from 6.4 to $7.3,6.2$ to 7.1 , and 6.6 to $7.9 \mathrm{~cm}$ at the Geneva-P, Geneva, and Ithaca sites, respectively (data not shown). Mean fruit width at the blossom end ranged from 5.3 to $5.8,5.2$ to 6.0 , and 5.5 to $6.6 \mathrm{~cm}$ at the Geneva-P, Geneva, and Ithaca sites, respectively, but there were no significant differences among varieties or breeding lines at any of the sites (data not shown).

Percent of otherwise marketable fruit affected by silvering varied significantly among varieties and breeding lines at all three sites, but patterns were not always consistent across sites (Table 4 ). While a comparatively large percentage of fruit from PcapNY8001-1 were affected by silvering at the Geneva site, comparatively small percentages of Pcap-NY8001-1 fruit were affected by silvering at the other two sites. Similarly, comparatively little silvering was observed on fruit from Pcap-NY8007-1 at the Geneva and Geneva-P sites, but the percent of Pcap-NY8007-1 fruit with silvering at the Ithaca site was not significantly different than 'Paladin', which had the highest percent of fruit affected by silvering at this site. At all three sites, 'Paladin' and 'Intruder' tended to have more fruit affected by silvering, and only at the Ithaca site did 'Aristotle' have significantly less fruit affected by silvering compared with these two varieties. In general, silvering was more common at the Ithaca site, with high levels observed in the phytophthorasusceptible varieties Red Knight and Vanguard, in addition to Paladin and Intruder (Table 4).

Although harvest date was a significant factor in predicting marketable yield at all field sites based on the repeated measures analysis, differences in marketable yield among varieties and breeding lines within each harvest date were not always significant. At the Geneva site, there were no significant differences between varieties at any of the harvest dates, but yields ranged from 1.22 to $2.64,0.99$ to $3.33,0.50$ to 5.22 , and 0.21 to $1.11 \mathrm{~kg}$ total marketable fruit weight per 10 plants at the first, second, third, and fourth harvest dates, respectively (data not shown). At the Ithaca site, yield per 10 'Paladin' plants $(2.46 \mathrm{~kg})$ was significantly larger than for any other variety or breeding line ( 0 to $0.50 \mathrm{~kg}$, each) at the first harvest date. At all other harvest dates, differences among varieties were not significant, and yields ranged from 3.52 to 7.91 , 4.29 to 6.63 , and 1.95 to $3.76 \mathrm{~kg}$ per 10 plants at the second, third, and fourth harvests, respectively (data not shown). At the Geneva-P site, yields were largest among tolerant commercial varieties (Paladin, Intruder, and Aristotle) at the first two harvest dates, but yields from the breeding lines were either relatively consistent over the four harvest dates, or in some cases increased at later dates (Table 5). Yields from the five susceptible varieties (Vanguard, Declaration, Revolution, Karisma, and Red Knight) tended to be smaller across all harvest dates at the Geneva-P site compared with 'Paladin', 'Intruder', and 'Aristotle' (the most tolerant varieties). However, these differences were not significant at the third and fourth harvest dates or for 'Vanguard' at any of the harvest dates. 
There were few significant differences among varieties and breeding lines in plant height or height to first fruit at either the Geneva or Ithaca sites, although the breeding lines tended to be shorter (numerically) than the commercial varieties (Table 6). Geneva-P site. Among 'Declaration' plants which survived to the first harvest at this site, plant height and height to first fruit were significantly reduced compared with one of the commercial varieties and three of the
However, this was not true at the

Table 2. Percent of marketable fruit classified as large [at least 3 inches $(7.6 \mathrm{~cm})$ in diameter] harvested over four dates at three field sites in New York State. At one site (Geneva-P), plants were inoculated with Phytophthora capsici on 24 June, and at the other two sites (Geneva and Ithaca), plants were not inoculated.

\begin{tabular}{|c|c|c|c|}
\hline \multirow[b]{2}{*}{ Variety or breeding line } & \multicolumn{3}{|c|}{ Large fruit $(\%)^{z}$} \\
\hline & Geneva-Py $^{y}$ & Geneva & Ithaca \\
\hline Declaration & & $66.7 \mathrm{a}$ & $98.0 \mathrm{a}$ \\
\hline Vanguard & & $64.8 \mathrm{a}$ & $97.8 \mathrm{a}$ \\
\hline Revolution & & $58.1 \mathrm{ab}$ & $99.0 \mathrm{a}$ \\
\hline Red Knight $^{\mathrm{y}}$ & & $52.6 \mathrm{ab}$ & $95.5 \mathrm{a}$ \\
\hline Intruder & $41.8 \mathrm{ab}^{\mathrm{x}}$ & $52.0 \mathrm{ab}$ & $96.2 \mathrm{a}$ \\
\hline Aristotle & $36.8 \mathrm{abc}$ & $40.4 \mathrm{ab}$ & $95.0 \mathrm{ab}$ \\
\hline Paladin & $49.7 \mathrm{a}$ & $37.0 \mathrm{ab}$ & $96.0 \mathrm{a}$ \\
\hline Karisma & & $35.4 \mathrm{ab}$ & $96.8 \mathrm{a}$ \\
\hline Pcap-NY8001-1 & $23.4 \mathrm{abc}$ & $31.5 \mathrm{ab}$ & $85.3 \mathrm{bc}$ \\
\hline Pcap-NY8007-1 & $22.5 \mathrm{abc}$ & $21.4 \mathrm{~b}$ & $94.1 \mathrm{ab}$ \\
\hline Pcap-NY8002-3 & $21.4 \mathrm{bc}$ & $21.2 \mathrm{~b}$ & $84.0 \mathrm{c}$ \\
\hline Pcap-NY8006-1 & $13.4 \mathrm{c}$ & $20.5 \mathrm{~b}$ & $91.5 \mathrm{abc}$ \\
\hline$P$ value $^{\mathrm{w}}$ & 0.003 & $<0.001$ & $<0.001$ \\
\hline
\end{tabular}

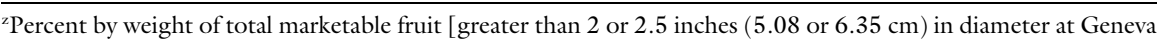
and Geneva-P, or Ithaca sites, respectively, and without blemishes from diseases, insects, or abiotic disorders] classified as large.

y At the Geneva-P site, only data from the seven most-tolerant varieties and breeding lines were included in the analysis since very few fruit were harvested from more susceptible varieties.

${ }^{x}$ Within a column, means followed by the same letter are not significantly different at $P<0.05$.

"Probability value for analyses of variance testing for significant differences among varieties and breeding lines. breeding lines, whereas 'Declaration' plants were not significantly shorter than other varieties or breeding lines at either the Geneva or the Ithaca site. Also, at the Geneva site, 'Red Knight' produced its first fruit significantly closer to the ground than did 'Intruder'. While this difference was not significant at the Ithaca site, the same trend was present. With the exception of two of the breeding lines (PcapNY8006-1 and Pcap-NY8007-1), plants inoculated with phytophthora blight tended to be shorter than uninoculated plants at the two healthy sites.

Plants of all varieties and breeding lines were generally upright, and little lodging was observed during the 8-week harvest period at either the Geneva or Geneva-P site. At the Ithaca site, plots of 'Declaration' plants tended to receive lower scores (i.e., more lodging) compared with other varieties or breeding lines at the midharvest rating, but differences were not statistically significant (data not shown). At both the Geneva and Geneva-P sites, fruit were consistently very easy to harvest from breeding line plants, while ease of harvest from commercial varieties was variable between plots of the same variety. At the Ithaca site, ease of harvest was similar

Table 3. Fruit characteristics of bell pepper varieties and breeding lines at three field sites in New York State. At one site (Geneva-P), plants were inoculated with Phytophthora capsici on 24 June, and at the other two sites (Geneva and Ithaca), plants were not inoculated. Data for only the seven most tolerant varieties and breeding lines are shown for the Geneva-P site since susceptible varieties produced little or no yield at this site because of disease pressure. All measurements are from marketable fruit, defined as greater than 2 or 2.5 inches $(5.08$ or $6.35 \mathrm{~cm})$ in diameter at Geneva and Geneva-P, or Ithaca sites, respectively, and without blemishes from diseases, insects, or abiotic disorders.

\begin{tabular}{|c|c|c|c|c|c|c|c|c|c|}
\hline \multirow{2}{*}{$\begin{array}{l}\text { Variety or } \\
\text { breeding line }\end{array}$} & \multicolumn{3}{|c|}{ Mean fruit wt $(\mathrm{g})^{\mathrm{z}}$} & \multicolumn{3}{|c|}{ Mean fruit length $(\mathrm{cm})^{\mathrm{y}}$} & \multicolumn{3}{|c|}{ Mean fruit with four lobes $(\%)^{x}$} \\
\hline & Geneva-P & Geneva & Ithaca & Geneva-P & Geneva & Ithaca & Geneva-P & Geneva & Ithaca \\
\hline Revolution & & 73 & $184 \mathrm{a}^{\mathrm{w}}$ & & $6.4 \mathrm{abc}$ & $8.1 \mathrm{abc}$ & & 50.0 & 63.8 \\
\hline Declaration & & 75 & $169 \mathrm{ab}$ & & $6.6 \mathrm{abc}$ & $8.0 \mathrm{abc}$ & & 55.0 & 61.3 \\
\hline Intruder & 128 & 75 & $169 \mathrm{ab}$ & $8.1 \mathrm{a}$ & $6.8 \mathrm{abc}$ & $8.6 \mathrm{a}$ & $32.5 \mathrm{~b}$ & 56.7 & 57.5 \\
\hline Karisma & & 88 & $166 \mathrm{abc}$ & & $7.5 \mathrm{ab}$ & $8.4 \mathrm{ab}$ & & 55.0 & 61.3 \\
\hline Vanguard & & 66 & 155 abcde & & $6.6 \mathrm{abc}$ & $8.2 \mathrm{abc}$ & & 56.7 & 57.5 \\
\hline Pcap-NY8002-3 & 109 & 79 & 137 bcde & $6.9 \mathrm{~b}$ & $6.3 \mathrm{abc}$ & $7.7 \mathrm{abc}$ & $60.0 \mathrm{a}$ & 45.0 & 61.3 \\
\hline Pcap-NY8006-1 & 81 & 60 & $129 \mathrm{cde}$ & $6.4 \mathrm{~b}$ & $5.8 c$ & $7.2 \mathrm{c}$ & $34.3 \mathrm{ab}$ & 41.7 & 46.3 \\
\hline Pcap-NY8007-1 & 89 & 66 & $127 \mathrm{de}$ & $6.3 \mathrm{~b}$ & $6.1 \mathrm{bc}$ & $7.5 \mathrm{bc}$ & $51.3 \mathrm{ab}$ & 51.6 & 56.3 \\
\hline Pcap-NY8001-1 & 107 & 75 & $124 \mathrm{e}$ & $6.7 \mathrm{~b}$ & $6.2 \mathrm{abc}$ & $7.2 \mathrm{c}$ & $40.0 \mathrm{ab}$ & 58.0 & 64.7 \\
\hline
\end{tabular}

${ }^{\mathrm{z}}$ Average weight per marketable fruit from the first harvest date (Geneva-P and Geneva sites) or the second harvest date (Ithaca site); $1 \mathrm{~g}=0.0353 \mathrm{oz}$.

yt the Geneva-P and Geneva sites, mean fruit length is based on 7-10 fruit per plot selected arbitrarily from all marketable fruit, and data from the first and second harvests were combined for analysis. Plots from which fewer than seven marketable fruit were harvested were excluded from the analysis. At the Ithaca site, mean fruit length is based on 10 fruit per plot selected arbitrarily from all marketable fruit, and data from the second and third harvests were combined for analysis; $1 \mathrm{~cm}=0.3937$ inch.

xercent of marketable fruit that had four lobes.

"Within a column, means followed by the same letter are not significantly different at $P<0.05$. The absence of letters indicates that there were no significant differences between varieties at this probability value.

vProbability value for analyses of variance testing for significant differences among varieties and breeding lines; Ns indicates $P \geq 0.05$. 
Table 4. Silvering in bell pepper varieties and breeding lines at three field sites in New York State. At one site (Geneva-P), plants were inoculated with Phytophthora capsici on 24 June, and at the other two sites (Geneva and Ithaca), plants were not inoculated.

\begin{tabular}{lccc}
\hline & \multicolumn{3}{c}{ Mean silvering (\%) $)^{\mathbf{z}}$} \\
\cline { 2 - 4 } Variety or breeding line & Geneva-P & Geneva & Ithaca \\
\hline Paladin & $12.9 \mathrm{a}^{\mathrm{x}}$ & $2.6 \mathrm{ab}$ & $25.4 \mathrm{a}$ \\
Red Knight & & $3.4 \mathrm{ab}$ & $24.6 \mathrm{a}$ \\
Intruder & $14.4 \mathrm{a}$ & $4.1 \mathrm{ab}$ & $21.8 \mathrm{ab}$ \\
Pcap-NY8007-1 & $3.2 \mathrm{~b}$ & $0 \mathrm{~b}$ & $20.2 \mathrm{abc}$ \\
Vanguard & & $0 \mathrm{~b}$ & $10.4 \mathrm{bcd}$ \\
Karisma & & $0 \mathrm{~b}$ & $8.4 \mathrm{bcd}$ \\
Pcap-NY8001-1 & $1.6 \mathrm{~b}$ & $4.5 \mathrm{a}$ & $7.7 \mathrm{~cd}$ \\
Aristotle & $6.1 \mathrm{ab}$ & $0.8 \mathrm{ab}$ & $3.6 \mathrm{~d}$ \\
Pcap-NY8006-1 & $1.1 \mathrm{~b}$ & $0 \mathrm{~b}$ & $3.0 \mathrm{~d}$ \\
Declaration & & $0.3 \mathrm{ab}$ & $1.9 \mathrm{~d}$ \\
Revolution & & $0.7 \mathrm{ab}$ & $1.7 \mathrm{~d}$ \\
Pcap-NY8002-3 & $2.2 \mathrm{~b}$ & $0.8 \mathrm{ab}$ & $1.3 \mathrm{~d}$ \\
P value & $<0.001$ & 0.005 & $<0.001$ \\
\hline
\end{tabular}

${ }^{2}$ Percent (by weight) of otherwise marketable fruit with at least 1 inch $^{2}\left(6.45 \mathrm{~cm}^{2}\right)$ of the fruit surface affected by silvering. Marketable fruit were defined as being greater than 2 or 2.5 inches $(5.08$ or $6.35 \mathrm{~cm})$ in diameter at Geneva and Geneva-P, or Ithaca sites, respectively, and without blemishes from diseases, insects, or abiotic disorders.

y Data for only the seven most-tolerant varieties and breeding lines are shown for the Geneva-P site since susceptible varieties produced little or no yield at this site because of disease pressure.

${ }^{x}$ Within a column, means followed by the same letter are not significantly different at $P<0.05$.

"Probability value for analyses of variances testing for significant differences among varieties and breeding lines.

Table 5. Marketable yields from bell pepper varieties and breeding lines at four harvest dates at a Geneva, NY, field site (Geneva-P) that had been inoculated with Phytophthora capsici on 24 June.

\begin{tabular}{lcccc}
\hline & \multicolumn{4}{c}{ Mean marketable yield (kg/10 plants) } \\
\cline { 2 - 5 } Variety or breeding line & Harvest $\mathbf{1}$ & Harvest 2 & Harvest 3 & Harvest 4 \\
\hline Paladin & $3.65 \mathrm{a}^{\mathrm{y}}$ & $2.24 \mathrm{a}$ & $0.87 \mathrm{ab}$ & $0.62 \mathrm{bc}$ \\
Intruder & $3.58 \mathrm{a}$ & $1.92 \mathrm{ab}$ & $1.08 \mathrm{ab}$ & $0.93 \mathrm{abc}$ \\
Aristotle & $2.42 \mathrm{ab}$ & $1.73 \mathrm{abc}$ & $1.44 \mathrm{ab}$ & $0.89 \mathrm{abc}$ \\
Pcap-NY8006-1 & $1.85 \mathrm{ab}$ & $1.67 \mathrm{abc}$ & $1.70 \mathrm{ab}$ & $1.95 \mathrm{ab}$ \\
Pcap-NY8002-3 & $1.85 \mathrm{ab}$ & $1.09 \mathrm{abcd}$ & $0.90 \mathrm{ab}$ & $1.29 \mathrm{abc}$ \\
Pcap-NY8001-1 & $1.67 \mathrm{ab}$ & $1.15 \mathrm{abcd}$ & $0.93 \mathrm{ab}$ & $1.41 \mathrm{abc}$ \\
Pcap-NY8007-1 & $1.31 \mathrm{ab}$ & $1.43 \mathrm{abcd}$ & $2.90 \mathrm{a}$ & $2.30 \mathrm{a}$ \\
Vanguard & $1.28 \mathrm{ab}$ & $0.46 \mathrm{bcd}$ & $0.32 \mathrm{~b}$ & $0.07 \mathrm{c}$ \\
Declaration & $1.06 \mathrm{~b}$ & $0.18 \mathrm{~cd}$ & $0.12 \mathrm{~b}$ & $0.02 \mathrm{c}$ \\
Revolution & $0.41 \mathrm{~b}$ & $0.11 \mathrm{~cd}$ & $0 \mathrm{~b}$ & $0.11 \mathrm{c}$ \\
Karisma & $0.37 \mathrm{~b}$ & $0.24 \mathrm{~cd}$ & $0.04 \mathrm{~b}$ & $0.03 \mathrm{c}$ \\
Red Knight & $0 \mathrm{~b}$ & $0 \mathrm{~d}$ & $0 \mathrm{~b}$ & $0 \mathrm{c}$ \\
Pvalue & $<0.001$ & $<0.001$ & $<0.001$ & $<0.001$
\end{tabular}

${ }^{2}$ Yields per 10 plants were based on the number of plants that were healthy when they were first inoculated with $P$. capsici on 24 June. Marketable fruit were defined as being greater than 2 inches $(5.08 \mathrm{~cm})$ in diameter and without blemishes from diseases, insects, or abiotic disorders; $1 \mathrm{~kg}=2.2046 \mathrm{lb}$.

'Within a column, means followed by the same letter are not significantly different at $P<0.05$

xProbability value for analyses of variances testing for significant differences among varieties and breeding lines.

among varieties, although some plots (primarily breeding lines) had no mature fruit ready for harvest at the first harvest date when data were collected (data not shown).

\section{Discussion}

With an increase in the prevalence of phytophthora blight in the northeastern United States, choosing a bell pepper variety with both disease tolerance and excellent horticultural characteristics is critical. Results from this study suggest that commercial varieties and breeding lines included in this trial were equally high yielding in weight but not fruit size, in the absence of phytophthora blight. The most tolerant commercial varieties maintained their yields under heavy disease pressure from a single New York isolate of the pathogen. Interestingly, although Revolution has been described as intermediately tolerant (Foster and Hausbeck, 2010; McGrath and Fox, 2009) and is frequently grown in commercial New York fields with a history of phytophthora blight, in this trial it did not yield any better than the susceptible variety Red Knight in the presence of phytophthora blight and had only slightly lower disease incidence. This could be related to the high level of disease pressure in the trial or to the specific isolate used in inoculation. Isolates of phytophthora blight can vary widely in their virulence on different pepper varieties, and some have been shown to be virulent on 'Revolution', as well as on 'Paladin' and 'Aristotle' (Foster and Hausbeck, 2010). It should also be noted that, while 'Paladin' showed high levels of tolerance in the present study, Ristaino and Johnston (1999) reported that it is susceptible to foliar infection by phytophthora blight. In on-farm and research trials, we have seen fruit rot and foliar symptoms of phytophthora blight on all the varieties and breeding lines included in this trial, in some cases including latent infections that may result in postharvest symptom development (A.R. Dunn and C.D. Smart, unpublished data). Using fungicide applications in combination with pepper varieties tolerant to root and stem rot can improve both plant survival and yield (McGrath and Fox, 2009).

As discussed previously, total weight of marketable fruit is not the sole criterion for selecting a bell pepper variety for fresh market production. While differences among commercial varieties were not significant in this trial, some of the most tolerant commercial varieties (especially, Paladin and Aristotle) did tend to produce smaller proportions of large fruit, compared with the more susceptible varieties. In a two-year study conducted in three fields across Pennsylvania, Sánchez et al. (2011) reported that 'Revolution', 'Intruder', 'Aristotle', 'Karisma', and 'Paladin' were all comparable in terms of total marketable yield. However, 'Revolution' surpassed these varieties (and all others in the trial) in terms of quantity of large fruit (defined as greater than 4 inches in diameter) produced. While differences were not significant in our trial, we saw similar trends in terms of percent of fruit with diameters greater 
Table 6. Plant height and height to first fruit of bell pepper varieties and breeding lines grown at three field sites. At one site (Geneva-P), plants were inoculated with Phytophthora capsici on 24 June, and at the other two sites (Geneva and Ithaca), plants were not inoculated. No data are available for 'Karisma' and 'Red Knight' from the Geneva-P site because all plants had already been killed by phytophthora blight in two and four of the blocks, respectively, by the time data were collected.

\begin{tabular}{|c|c|c|c|c|c|c|}
\hline \multirow{2}{*}{$\begin{array}{l}\text { Variety or } \\
\text { breeding line }\end{array}$} & \multicolumn{3}{|c|}{ Mean plant ht $(\mathrm{cm})^{\mathrm{z}}$} & \multicolumn{3}{|c|}{ Mean ht to first fruit $(\mathrm{cm})^{\mathrm{z}}$} \\
\hline & Geneva-P & Geneva & Ithaca & Geneva-P & Geneva & Ithaca \\
\hline Vanguard & $39.7 \mathrm{abc}^{\mathrm{y}}$ & $50.9 \mathrm{a}$ & $52.6 \mathrm{a}$ & $15.8 \mathrm{ab}$ & $16.5 \mathrm{ab}$ & 11.1 \\
\hline Declaration & $32.5 \mathrm{c}$ & $51.4 \mathrm{a}$ & $51.5 \mathrm{ab}$ & $6.6 \mathrm{~b}$ & $17.2 \mathrm{ab}$ & 9.5 \\
\hline Aristotle & $37.6 \mathrm{abc}$ & $46.2 \mathrm{ab}$ & $49.4 \mathrm{abc}$ & $13.4 \mathrm{ab}$ & $16.2 \mathrm{ab}$ & 8.3 \\
\hline Revolution & $35.8 \mathrm{bc}$ & $49.5 \mathrm{a}$ & $49.2 \mathrm{abcd}$ & $12.5 \mathrm{ab}$ & $15.5 \mathrm{ab}$ & 7.5 \\
\hline Karisma & & $49.1 \mathrm{ab}$ & $48.5 \mathrm{abcd}$ & & $17.0 \mathrm{ab}$ & 8.8 \\
\hline Paladin & $38.9 \mathrm{abc}$ & $45.4 \mathrm{ab}$ & $48.5 \mathrm{abcd}$ & $15.2 \mathrm{ab}$ & $16.1 \mathrm{ab}$ & 7.3 \\
\hline Intruder & $42.2 \mathrm{ab}$ & $53.7 \mathrm{a}$ & 47.5 bcde & $16.6 \mathrm{a}$ & $23.9 \mathrm{a}$ & 12.5 \\
\hline Red Knight & & $50.3 \mathrm{a}$ & 47.1 bcde & & $13.8 \mathrm{~b}$ & 7.5 \\
\hline Pcap-NY8006-1 & $43.8 \mathrm{a}$ & $44.4 \mathrm{ab}$ & 46.2 cde & $20.7 \mathrm{a}$ & $16.3 \mathrm{ab}$ & 8.6 \\
\hline Pcap-NY8002-3 & $40.4 \mathrm{ab}$ & $49.0 \mathrm{ab}$ & $46.0 \mathrm{cde}$ & $18.1 \mathrm{a}$ & $21.4 \mathrm{ab}$ & 10.6 \\
\hline Pcap-NY8007-1 & $40.9 \mathrm{ab}$ & $38.6 \mathrm{~b}$ & 44.9 de & $16.1 \mathrm{ab}$ & $18.8 \mathrm{ab}$ & 7.4 \\
\hline Pcap-NY8001-1 & $38.9 \mathrm{abc}$ & $44.5 \mathrm{ab}$ & $43.6 \mathrm{e}$ & $20.2 \mathrm{a}$ & $18.1 \mathrm{ab}$ & 9.7 \\
\hline$P$ value $^{\mathrm{x}}$ & 0.003 & 0.003 & $<0.001$ & 0.003 & 0.05 & NS \\
\hline
\end{tabular}

${ }^{\mathrm{z}} 1 \mathrm{~cm}=0.3937$ inch.

'Within a column, means followed by the same letter are not significantly different at $P<0.05$. The absence of letters indicates that there were no significant differences between varieties at this $P$ value.

${ }^{x}$ Probability value for analyses of variances testing for significant differences among varieties or breeding lines. NS indicates $P>0.05$

than 3 inches, and average fruit weight of 'Revolution' compared with the other four varieties this trial had in common with the Pennsylvania study.

Similar to previous reports of increased silvering in phytophthoratolerant bell pepper varieties (Kline et al., 2011), 'Paladin' and 'Intruder' did have comparably high levels of silvering at all three sites in this trial, while incidence of silvering in Aristotle fruit was high at only one of the three sites. In spite of this, total marketable yields from 'Paladin' and 'Intruder' were not significantly lower than yields from other commercial varieties with less silvering. Thus, in this study, marketable yields from 'Paladin' and 'Intruder' were still competitive with other commercial varieties, in spite of losses due to silvering. Incidence of silvering was low in 'Revolution' at both the Geneva and Ithaca sites. It is not clear why differences in silvering among varieties were not consistent across the three sites in the present study, or why much higher incidence of silvering was observed at the Ithaca site than at the other two sites. However, Wyenandt and Kline (2006) previously reported differences in percent of fruit affected by silvering between two locations (although cultural practices differed between the locations).
Kline et al. (2011) also speculated that environmental conditions (including soil moisture, soil and air temperature, or their fluctuation over time) may contribute to levels of silvering. While variety is likely not the only factor that influences fruit silvering in pepper, it is an important factor, and bell pepper varieties that are less prone to silvering are needed.

The fact that some stunting was observed in all varieties, and two of the four breeding lines in the presence of phytophthora blight suggests that the disease is affecting even plants that do not wilt or die following inoculation. It seems likely that this stunting would affect marketable yield, although this trial provides no evidence of that. However, since uninoculated plants were grown in different fields than inoculated plants (with different soil types), it is difficult to make yield comparisons between inoculated and uninoculated plants. While disease incidence was high in 'Declaration', plants that did survive were also shorter and bore fruit closer to the ground than 'Intruder' and three of the breeding lines. This could result in increased vulnerability of fruit on surviving 'Declaration' plants to spores of phytophthora blight splashed from the soil during heavy rain or overhead irrigation.
The four breeding lines included in this trial have excellent tolerance to phytophthora blight, with total marketable fruit weights comparable to commercial varieties (with and without disease pressure). In addition, some had comparable proportions of fruit with four lobes (relative to commercial varieties), and Pcap-NY8006-1 and Pcap-NY8002-3 showed consistently low incidence of silvering across all three field sites. Fruit from the breeding lines tended to be smaller (in terms of diameter, weight, and length). Although they are not suited to production of early, extra large fruit, their high degree of phytophthora tolerance results in extended harvests when grown in infested soil.

\section{Conclusion}

The results of this trial suggest that 'Intruder', 'Paladin', and 'Aristotle' are good choices for fresh market green bell pepper production on farms in the northeastern United States with a history of heavy disease pressure from phytophthora blight, although silvering is a concern, especially for 'Intruder' and 'Paladin'. All three varieties yielded well in the presence and absence of phytophthora blight, suggesting that they will perform well even in fields where phytophthora blight severity varies from year to year. In addition, it is possible that a field population of phytophthora blight could overcome the host tolerance in a pepper variety if that variety is extensively and continuously planted in a field. Therefore, fields with a history of phytophthora blight should be carefully monitored for increased disease incidence on previously tolerant varieties. Especially in fields with high inoculum levels, an integrated approach that uses host tolerance, cultural practices (including crop rotation), and fungicides is recommended for successful management of this disease. This study also highlights the need for additional phytophthoratolerant bell pepper varieties that produce large fruit and are less prone to silvering.

\section{Literature cited}

Bowers, J.H. and D.J. Mitchell. 1990. Effect of soil-water matric potential and periodic flooding on mortality of pepper caused by Phytophthora capsici. Phytopathology 80:1447-1450. 
Crosby, K.M. 2008. Pepper, p. 221-248. In: J. Prohens and F. Nunez (eds.). Vegetables II. Springer, New York, NY.

de Mendiburu, F. 2012. Statistical procedures for agricultural research. Version 1.1-3. 11 Apr. 2012. <http://tarwi.lamolina. edu.pe $/ \sim$ fmendiburu $>$.

Dunn, A.R., M.G. Milgroom, J.C. Meitz, A. McLeod, W.E. Fry, M.T. McGrath, H.R. Dillard, and C.D. Smart. 2010. Population structure and resistance to mefenoxam of Phytophthora capsici in New York State. Plant Dis. 94:1461-1468.

Foster, J.M. and M.K. Hausbeck. 2010. Resistance of pepper to Phytophthora crown, root, and fruit rot is affected by isolate virulence. Plant Dis. 94:24-30.

Fox, J. and S. Weisberg. 2011. An R companion to applied regression. 2nd ed. Sage Publ., Thousand Oaks, CA.

Granke, L.L., L. Quesada-Ocampo, K. Lamour, and M.K. Hausbeck. 2012. Advances in research on Phytophthora capsici on vegetable crops in the United States. Plant Dis. 95:1588-1600.

Hutton, M.G. and D.T. Handley. 2007. Bell pepper cultivar performance under short, variable growing seasons. HortTechnology 17:136-141.

Jackson, K.L., J. Yin, and P. Ji. 2012. Sensitivity of Phytophthora capsici on vegetable crops in Georgia to mandipropamid, dimethomorph and cyazofamid. Plant Dis. 96:1337-1342.

Keinath, A.P. 2007. Sensitivity of populations of Phytophthora capsici from South
Carolina to mefenoxam, dimethomorph, zoxamide, and cymoxanil. Plant Dis. 91:743-748.

Kline, W.L., C.A. Wyenandt, D.L. Ward, J.F. Sudal, and N.L. Maxwell. 2011. Evaluation of six nitrogen fertility programs on marketable yield and development of skin separation in bell pepper fruit. HortTechnology 21:323-328.

Leonian, L.H. 1922. Stem and fruit blight of peppers caused by Phytophthora capsici sp. nov. Phytopathology 12:401-408.

McGrath, M.T. and G.M. Fox. 2009. Evaluation of Phytophthora-resistant bell pepper cultivars with and without a fungicide program, 2008. Plant Dis. Mgt. Rpt. 3:V132.

Mchau, G.R.A. and M.D. Coffey. 1995. Evidence for the existence of two subpopulations in Phytophthora capsici and a redescription of the species. Mycol. Res. 99:89-102.

Ortega, R.G., C.P. Español, and J.C. Zueco. 1992. Genetic relationships among four pepper genotypes resistant to Phytophthora capsici. Plant Breed. 108:118-125.

R Development Core Team. 2012. R: A language and environment for statistical computing. 11 Apr. 2012. <http://www. R-project.org/>.

Ristaino, J.B. and S.A. Johnston. 1999. Ecologically based approaches to management of Phytophthora blight on bell pepper. Plant Dis. 83:1080-1089.
Sánchez, E.S., T.M. Butzler, S.M. Bogash, T.E. Elkner, R.E. Oesterling, M.D. Orzolek, and L.J. Stivers. 2011. Pennsylvania statewide bell pepper cultivar evaluation. HortTechnology 21:384390.

Sy, O., P.W. Bosland, and R. Steiner. 2005. Inheritance of Phytophthora stem blight resistance as compared to Phytophthora root rot and Phytophthora foliar blight resistance in Capsicum annuиm L. J. Amer. Soc. Hort. Sci. 130:75-78.

U.S. Department of Agriculture. 2005. United States Standards for Grades of Sweet Peppers. 31 Dec. 2012. <http:// www.ams.usda.gov/AMSv1.0/getfile? dDocName=STELPRDC5050318 $>$.

U.S. Department of Agriculture. 2012a. New York Agriculture Statistics Annual Bulletin 2012. 29 Dec. 2012. <http:// www.nass.usda.gov/Statistics_by_State/ New_York/Publications/Annual_Statistical_ Bulletin/2012/2012-bulletin.htm>.

U.S. Department of Agriculture. 2012b. Vegetables Summary 2011.29 Dec. 2012. <http://usda01.library.cornell.edu/ usda/current/VegeSumm/VegeSumm01-26-2012.pdf>.

Wiant, J.S. and C.M. Tucker. 1940. A rot of Winter Queen water-melons caused by Phytophthora capsici. J. Agr. Res. 9:73-88.

Wyenandt, C.A. and W.L. Kline. 2006. Evaluation of skin separation (silvering) in fruit of bell pepper cultivars. HortScience 41:494 (abstr.). 